Meta

Journal des traducteurs

Translators' Journal

\title{
Foreign Language Anxiety in Taiwanese Student Interpreters
}

\section{Yung-Nan Chiang}

Volume 54, numéro 3, septembre 2009

URI : https://id.erudit.org/iderudit/038318ar

DOI : https://doi.org/10.7202/038318ar

Aller au sommaire du numéro

\section{Éditeur(s)}

Les Presses de l'Université de Montréal

ISSN

0026-0452 (imprimé)

1492-1421 (numérique)

Découvrir la revue

Citer cet article

Chiang, Y.-N. (2009). Foreign Language Anxiety in Taiwanese Student Interpreters. Meta, 54(3), 605-621. https://doi.org/10.7202/038318ar

\section{Résumé de l'article}

Bien que le rôle déterminant de l'anxiété ait été démontré autant en situation d'interpération que dans le cadre de l'acquisition d'une langue seconde (L2), pratiquement aucun dialogue n'a été établi entre ces deux domaines. Afin de combler ce vide, la présente étude analyse l'anxiété liée à l'usage d'une langue étrangère (LE) chez des étudiants en interprétariat de Taïwan au cours de leurs premières années universitaires. La mesure de l'anxiété est fondée sur l'échelle d'anxiété en classe de langue étrangère mise au point par Horwitz, Horwitz et al. (1986). Les résultats ont révélé : a) que malgré leur aptitude pour les langues, qui était attendue, ces étudiants éprouvaient une anxiété liée à l'usage d'une LE ; b) que la prévalence de cette anxiété était lègèrement moins importante que chez des apprenants asiatiques en L2, aussi importante que chez des apprenants américains en L2 et beaucoup plus importante que chez les apprenants européens en L2 ; c) que leur anxiété était légèrement moins intense que chez la plupart des étudiants d'appartenances culturelles diverses, toutes langues cibles confondues, à l'exception des étudiants américains de l'arabe et du russe. Enfin, la présente étude discute des implications pédagogiques de ces résultats et propose des orientations de recherches futures.
Ce document est protégé par la loi sur le droit d'auteur. L'utilisation des services d'Érudit (y compris la reproduction) est assujettie à sa politique d'utilisation que vous pouvez consulter en ligne.

https://apropos.erudit.org/fr/usagers/politique-dutilisation/ 


\title{
Foreign Language Anxiety in Taiwanese Student Interpreters
}

\author{
YUNG-NAN CHIANG \\ National Taipei University of Technology, Taipei, Taiwan \\ yungnan2@yahoo.com
}

\begin{abstract}
RÉSUMÉ
Bien que le rôle déterminant de l'anxiété ait été démontré autant en situation d'interpération que dans le cadre de l'acquisition d'une langue seconde (L2), pratiquement aucun dialogue n'a été établi entre ces deux domaines. Afin de combler ce vide, la présente étude analyse l'anxiété liée à l'usage d'une langue étrangère (LE) chez des étudiants en interprétariat de Taïwan au cours de leurs premières années universitaires. La mesure de l'anxiété est fondée sur l'échelle d'anxiété en classe de langue étrangère mise au point par Horwitz, Horwitz et al. (1986). Les résultats ont révélé: a) que malgré leur aptitude pour les langues, qui était attendue, ces étudiants éprouvaient une anxiété liée à l'usage d'une LE; b) que la prévalence de cette anxiété était lègèrement moins importante que chez des apprenants asiatiques en L2, aussi importante que chez des apprenants américains en $L 2$ et beaucoup plus importante que chez les apprenants européens en L2; c) que leur anxiété était légèrement moins intense que chez la plupart des étudiants d'appartenances culturelles diverses, toutes langues cibles confondues, à l'exception des étudiants américains de l'arabe et du russe. Enfin, la présente étude discute des implications pédagogiques de ces résultats et propose des orientations de recherches futures.
\end{abstract}

\begin{abstract}
Although anxiety has been found to be a key variable in both interpretation performance and second language (L2) acquisition, there has been virtually no dialogue between these two fields. In order to bridge this gap, this study investigated Taiwanese undergraduate student interpreters' foreign language (FL) anxiety using Horwitz, Horwitz et al.'s (1986) Foreign Language Classroom Anxiety Scale. Results showed that (1) Taiwanese student interpreters did have FL anxiety despite the language facility expected from them; (2) the scope of their FL anxiety was slightly less prevalent than regular Asian L2 learners, as widespread as American L2 learners, and more far-reaching than European L2 learners; and (3) the level of their FL anxiety was slightly less severe than in most of the university students from several cultural groups with various L2s, except for American college students of Arabic and Russian. Implications for pedagogy and future research are suggested.
\end{abstract}

\section{MOTS-CLÉS/KEYWORDS}

anxiété liée à l'interprétariat, anxiété liée à l'usage d'une langue étrangère, interprétation chinois-anglais, étudiants en interprétration

interpretation anxiety, foreign language anxiety, Chinese-English interpretation, student interpreters 


\section{Introduction}

In the field of interpretation, many scholars have stated that interpretation is a highly anxiety-provoking activity (e.g., Jiménez and Pinazo 2001; Seleskovitch 1978). Likewise, in the field of second language ${ }^{1}$ (L2) acquisition, many scholars have also documented that anxiety is a feeling shared by many L2 learners in language classrooms (e.g., Campbell and Ortiz 1991; Horwitz and Young 1991). Despite the fact that anxiety has been found to be an important variable in both interpretation and L2 acquisition research, there has been virtually no dialogue between these two fields. In particular, although interpretation generally involves one or even two L2s, available empirical interpretation anxiety studies have largely ignored the possibility that the interpreter's anxiety might be an anxiety unique to or compounded by using an L2 (e.g., Gerver 1974; Jiménez and Pinazo 2001; Kurz 1997; Riccardi, Marinuzzi et al. 1998).

In order to help fill this void, this study examined the probable existence of foreign language (FL) anxiety in Taiwanese student interpreters. Horwitz, Horwitz, et al.'s (1986) theory of FL anxiety was used as a theoretical framework in this study: according to the researchers, FL anxiety parallels three types of performance anxieties, including communication apprehension, test anxiety, and fear of negative evaluation (Horwitz, Horwitz et al. 1986: 30); however, FL anxiety is not merely the sum nor the transfer of these three types of performance anxieties, but "a distinct complex of self-perceptions, beliefs, feelings, and behaviors related to classroom language learning arising from the uniqueness of the language learning process" (Horwitz, Horwitz et al. 1986: 31). Accordingly, these authors' Foreign Language Classroom Anxiety Scale (FLCAS), which reflects their conceptualization of FL anxiety, was used to measure the participants' FL anxiety in order to address the following research questions:

1. What is the scope of FL anxiety in student interpreters as assessed by the individual FLCAS items and by the FLCAS overall?

2. What is the severity of FL anxiety in student interpreters as measured by the individual FLCAS items and by the FLCAS overall?

3. Is the level of FL anxiety the same as the pooled FL anxiety in regular L2 college students?

\section{Literature review}

Interpretation is highly anxiety-provoking in that the entire process of interpretation can be derailed at any time by numerous factors, such as poor speakers, difficult accents and technical deficits (Riccardi, Marinuzzi, et al. 1998). The ability to manage stress or anxiety ${ }^{2}$ is an important predictor of interpretation competence (Alexieva 1997; Coughlin 1988; Moser-Mercer, Kunzli, et al. 1998) and an essential element for successful interpretation performance (Cooper, Davis, et al. 1982; Gile 1995; Herbert 1952; Keiser 1977; Klonowicz 1991, 1994; Moser-Merser 2003; Roland 1982; Seleskovitch 1978). In fact, the ability to control anxiety was one of the primary criteria for selecting interpreters at the Nuremberg Trials, the symbolic birthplace of simultaneous interpretation (Gaiba 1998). Despite the important role ascribed to anxiety in interpretation performance, only a small number of empirical studies have been conducted (Brisau, Godjins, et al. 1994), and they will be reviewed here according to how anxiety was measured. ${ }^{3}$ 
Two studies used trait anxiety scales to measure interpreters' anxiety. Suspecting that highly anxious persons might have a low tolerance for noise, Gerver (1974) used the Eysenck Personality Inventory (EPI) to measure 12 interpreters' anxiety. He found that anxiety and simultaneous interpretation performance had a significant and negative correlation at the highest level of noise, a positive but non-significant relationship under slightly noisy conditions, and no relationship in good listening conditions. Riccardi, Marinuzzi, et al. (1998) regarded anxiety and depression as two stress factors and employed the ASQ-IPAT Anxiety Scale, the CDQ3-IPAT Depression Scale, the IMMPI-2 (Minnesota Multiphasic Personality Inventory) to assess 30 interpretation students' and 15 professional interpreters' levels of anxiety and depression during a mock conference and under real working conditions, respectively. The participants were found to have lower anxiety and depression values than normal sample population, with interpreters' scores lower than students'. These results were seen as confirming the important roles anxiety and depression play in determining one's decision to pursue interpretation as a career or a course of study.

Two studies employed state anxiety scales. Moser-Mercer, Kunzli et al. (1998) defined anxiety as one of the three stress emotions (i.e., anxiety, depression, and aggressiveness), and employed a questionnaire, which "presented the subjects with prototypical stressful situation-sequences” (Moser-Mercer, Kunzli et al. 1998: 57), to measure five conference interpreters' psychological stress (while using cortisol levels to assess their physiological stress). Results showed that the participants' psycho-physiological stress increased in the first 30 minutes, but decreased after more than 30 minutes, while interpretation quality deteriorated dramatically during the second 30 minutes. Jiménez and Pinazo (2001) conceived anxiety as being a result of fear of public speaking, and utilized Spielberger and Gorsuch's (1983) State Anxiety Inventory to measure anxiety. They found that fear of public speaking and anxiety had a significant positive correlation, whereas neither fear of public speaking nor anxiety was negatively related to student interpreters' mid-term exam performance.

Two studies used a combination of trait and state anxiety scales. Conceiving anxiety as a symptom of job stress, Kurz (1997) employed Spielberger and Gorsuch's (1983) State-and-Trait Anxiety Inventory to assess 32 conference interpreters' stress. She found that while most of the interpreters' trait and state anxiety scores were lower than those of an age-matched reference group, about one-third of them reported higher trait anxiety, but their state anxiety scores were also found to be significantly lower than their age-matched peers'. Construing the interpreters' lower state anxiety scores as an indicator of their ability to contain their anxiety and maintain their interpretation performance, Kurz (1997) concluded that although the interpreters were not homogeneous in their trait anxiety, they all qualified as consistent performers. A combination of trait and state anxiety scales were also used in Moser-Mercer's (2003) study. With a sample of 12 conference interpreters, the researcher sought to compare the effects of remote interpretation and live interpretation on psychological and physiological stress and fatigue (measured by the EPI, the STAI, and levels of cortisol). Interpreters working under remote conditions were found to be under more stress, although the results did not reach statistical significance. When comparing the effects of fatigue on performance for the same interpreter working either live or in remote condition, significant difference was found. 
While the above studies utilized validated anxiety measurement instruments, another study called the Workload Study (AIIC 2002) included a section called evaluating stress in its attitude questionnaire in a complex research design in which anxiety was seen as the second stage in the development of burnout among stressedout interpreters. A combination of a world-wide mail survey and an in-depth, on-site study was adopted in order to examine the interrelationship between psychological, physiological, physical factors that may affect performance, burnout, and stress. Major findings of the worldwide survey of 607 interpreters were similar to those of a previous AIIC-sponsored study (Cooper, Davis et al. 1982): high levels of mental stress, exhaustion and job-related fatigue were found among the respondents, with difficult source texts, poor booth conditions, poor speakers, and insufficient preparation being the primary stressors. In addition, of 52 questionnaires completed by interpreters at work, although 40-60\% reported that their performance deteriorated as a result of stress, both psychological stress and physiological stress were found to have weak correlations with performance quality as measured by delivery, linguistic correctness and meaning equivalence.

In sum, despite the consensus that anxiety is an important variable in interpretation, consensus about the construct of anxiety is lacking. Not only do most researchers use the terms stress and anxiety interchangeably as if they were the same in most studies, but even when stress is seen by some as a larger construct subsuming anxiety, the distinction ultimately collapses: for whenever interpreters' stress is under study, the stress construct is almost always operationalized by either trait anxiety scales, or state anxiety scales, or a combination of both. Except for the Workload Study (AIIC, 2002), available interpretation anxiety research appears to treat interpretation anxiety as a transfer of other more general types of anxiety. The Workload Study (AIIC, 2002) research approach is a step in the right direction in that its attitude questionnaire included specific stressors of conference interpreting in its item pool. Like the rest of the studies reviewed here, however, it also fails to fully address the issue of anxiety specific to using an L2 - a variable which L2 acquisition researchers have found to exert differential impacts on cognitive processing in L1 and L2 (MacIntyre and Gardner 1991, 1994; Dijgunovic 2006), but the impact of which on interpreting is still unknown. Before the impact of L2-specific anxiety on the process and product of interpreting can be known, the presence or absence of L2-specific anxiety in interpreters must first be ascertained.

As shown in the above literature review, existing research in interpretation anxiety has ignored the role of L2-specific anxiety in interpreters. Hence, in order to help fill this gap in our knowledge, this study investigated the probable existence of FL anxiety in Taiwanese student interpreters.

\section{Method}

The research design for the present study is reported below, including participants, instruments, and procedures of data collection and analysis.

\subsection{Participants}

The participants were 327 interpretation students from nine higher-education institutions across Taiwan. They were learning Chinese-English interpretation ${ }^{4}$ at four 
universities in northern Taiwan, three universities in central Taiwan, and two universities in southern Taiwan. This sample was representative of the undergraduate population learning Chinese-English interpretation in Taiwan in that the participants came not only from Taiwan's three major geographic regions, but also from universities ranging from the most prestigious to middle-ranked to the less prestigious. As is typical of the language departments in Taiwan, the majority of the participants $(77.1 \%)$ were women, with a female-male ratio of 252: 75. Their age ranged from 20 to 30, with an average age of 21.5. All of them had formal schooling in English for at least six years.

\subsection{Instruments}

Two instruments were used, including a Background Information Questionnaire (BIQ) and Horwitz, Horwitz et al.'s (1986) Foreign Language Classroom Anxiety Scale (FLCAS). The BIQ was devised to collect important demographic information about the subjects, such as gender and age. The FLCAS is a 33-item self-report instrument designed to measure anxiety that FL learners experience in the language classroom. The internal consistency of the FLCAS using Cronbach's alpha was 0.93 with a sample of 108 students (Horwitz 1986). Test-retest reliability over a period of eight weeks was $r=0.83(\mathrm{p}<0.01)$ with a sample of 78 subjects. In the present study, using Cronbach's alpha, the FLCAS had an internal consistency of 0.94 , indicating that FL anxiety as measured by the Chinese version of the FLCAS was highly reliable.

\subsection{Data Collection and Analysis Procedures}

The data were collected in the fall of 2004 . The questionnaires were administered to the participants during one of their class hours with the assistance of the instructors. A 5-point Likert scale was used to score the items of the FLCAS, including responses 1 strongly disagree, 2 disagree, 3 neither disagree nor agree, 4 agree, and 5 strongly agree. In other words, the score of FLCAS has a theoretical range from 33 to 165, with 99 as its neutral mean (i.e., when the 33-item FLCAS receive an average rating of 3 neither disagree nor agree on the 5-point Likert scale). The subjects' responses were scored in such a way that higher scores indicated higher anxiety and lower scores indicated lower anxiety. The participants' responses were entered into SPSS files and processed by computer. Descriptive statistics and meta-analyses were used to address the research questions.

\section{Results}

\subsection{Scope of Student Interpreters' FL Anxiety by Individual FLCAS items}

According to the participants' responses to the FLCAS, most of the participants (64.3\%) did not "feel more tense and nervous" in their English classes than in other classes, and 67\% disagreed or strongly disagreed that they often felt like not going to their English classes. A bit over one-half rejected statements like "I feel overwhelmed by the number of rules I have to learn in order to speak English" (55.6\%), and "Even if I am well-prepared for English classes, I still feel anxious about them" (57.5\%). Nearly one half (49.4\%) disagreed with the item that "English classes move so quickly 
I worry about getting behind." It seemed that English classes were not particularly anxiety provoking for slightly over one-half of the subjects in this study, including testing situations: $56.1 \%$ agreed that it would not bother them at all to take more English classes, 56.3\% rejected the statement that "the more I study for an English test, the more confused I get," and $59.7 \%$ did not worry about the consequences of failing their English class, though about one-third of the respondents did.

However, one-third of the subjects (30\%) reported that in English classes, they could get so nervous that they forgot things they knew, and slightly more than onethird (32.4\%) rejected the statement, "I don't understand why some people get so upset over English classes." Likewise, slightly over one-third (31.2\%) disagreed with the statement, "When I am on my way to English classes, I feel very sure and relaxed." About one-third of the subjects consistently felt anxious about English classes, including situations involving tests: $27.2 \%$ rejected the statement that they were usually at ease during English tests. It seemed that around 30\% of Taiwanese interpretation students suffered from moderate to high levels of FL anxiety. With respect to listening, more than one-third agreed with statements like, "It frightens me when I don't understand what the teacher is saying in English" (40.6\%), and "I get nervous when I don't understand what the English teacher says in English" (32.3\%). More than one-half endorsed the statement, "I get upset when I don't understand what the English teacher is correcting in English" (53.8\%). It seemed that at least one-third of the respondents suffered from FL listening comprehension anxiety, especially when the language input was from the instructor.

Similar to aural anxiety, speaking was equally anxiety-provoking to over onethird of the participants: $38.8 \%$ reported that they started to panic when they had to speak in English without preparation in English classes; 34\% rejected the statement, "I would not be nervous speaking English with native speakers"; and 34\% rejected the item, "I would probably feel comfortable around native speakers of English." Likewise, $36.7 \%$ agreed that they kept thinking that the other students were better at English than they were, 39.1\% always felt that other students spoke English better than they did, and $28.7 \%$ did not feel confident when they spoke English in English classes. It seemed that impromptu speech, interaction with native speakers of English, feelings of inferiority, and low self-confidence were causes of FL speaking anxiety for at least one-third of the students. Question-and-answer sessions, in particular, were anxiety-inducing for most of the students, especially when they had to think on their feet to answer the questions: $50.3 \%$ endorsed the item, "I get nervous when the English teacher asks questions which I have not prepared in advance," and 54.5\% reported they could feel their heart pounding when they were going to be called upon in English classes.

\subsection{Scope of Student Interpreters' FL Anxiety by FLCAS Overall}

In order to determine the exact scope of FL anxiety as measured by overall FLCAS, the neutral point of 99 on the 33-item FLCAS was used as a cut-off point. As discussed in the section on data analysis procedures, 99 is the neutral mean of all the possible FLCAS scores. Hence, those with a mean exceeding 99 were categorized as with FL anxiety. Those with a mean of 99 or less were categorized as without FL anxiety. Results showed that while $67.4 \%$ of the students were without FL anxiety, $32.6 \%$ had 
FL anxiety. Figure 1 displays the scope of FL anxiety in the entire sample of student interpreters in the present study as compared with those of regular L2 learners from different cultures.

\section{FIGURE 1}

Scope of FL Anxiety in Student Interpreters vs Regular L2 Learners

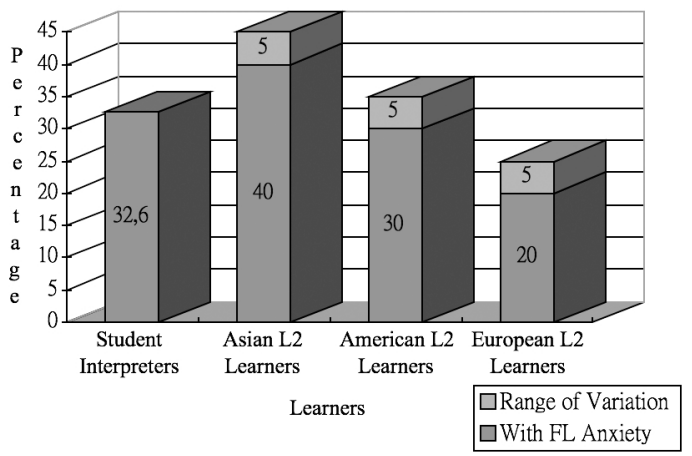

As shown in Figure 1, the scope of FL anxiety in interpretation students $(32.6 \%)$ appeared to be in the same range as that of regular L2 learners. According to Horwitz (2005), the scope of FL anxiety varied slightly across different culture groups: for European L2 learners, approximately 20 to 25\% had FL anxiety; for American L2 learners, approximately 30 to $35 \%$ had FL anxiety; and for Asian L2 learners, approximately 40 to $45 \%$ had FL anxiety. Thus, FL anxiety in Taiwanese interpretation students was slightly less prevalent than in other Asian L2 learners, but was as widespread as in American L2 learners, and was more far-reaching than in European L2 learners.

\subsection{Severity of FL Anxiety in Student Interpreters by Individual FLCAS Items}

Table 1 presents individual FLCAS items whose mean exceeds the neutral mean of 3 on the 5 point Likert-type scale in descending order.

TABLE 1

Severity of FL Anxiety in Student Interpreters by Individual FLCAS Items

\begin{tabular}{|clcc|}
\hline Rank & \multicolumn{1}{c}{ Item Description } & M & SD \\
\hline 1 & I can feel my heart pounding when I am going to be called on in English class. & 3.40 & 0.98 \\
\hline 2 & $\begin{array}{l}\text { I get upset when I don't understand what the English teacher is correcting in } \\
\text { English. }\end{array}$ & 3.36 & 0.92 \\
\hline 3 & $\begin{array}{l}\text { I get nervous when the English teacher asks questions which I haven't } \\
\text { prepared in advance. }\end{array}$ & 3.33 & 0.93 \\
\hline 4 & I always feel that the other students speak English better than I do. & 3.17 & 0.94 \\
\hline 5 & It frightens me when I don't understand what the teacher is saying in English. & 3.15 & 0.96 \\
\hline 6 & I keep thinking that the other students are better at English than I am. & 3.13 & 0.93 \\
\hline 7 & I don't understand why some people get so upset over English classes. & 3.08 & 0.95 \\
\hline 8 & I feel confident when I speak English in English class. & 3.08 & 0.81 \\
\hline 9 & $\begin{array}{l}\text { I start to panic when I have to speak in English without preparation in English } \\
\text { class. }\end{array}$ & 3.06 & 1.03 \\
\hline
\end{tabular}


As shown in Table 1, a total of nine FLCAS items exceeded the neutral mean of 3, suggesting that these various specific situations provoked anxiety for the sample as a whole. The most anxiety-provoking situation for student interpreters was to be called on to speak English in English class, followed by the situation where they could not understand what the English teacher was correcting in English. Like the item with the highest mean, the item with the third highest mean was also an item tapping English classroom performance anxiety, but was related to the situation when student interpreters were being asked to answer the English teacher's questions for which they had not prepared. Together, these three items suggested that although the ability to speak and comprehend English was the foundation of interpretation ability, these student interpreters found both aural and oral English anxiety-provoking. In addition, three items tapping inferiority complex (rank 4 and 6) or low self-confidence (rank 8) also had means exceeding 3, indicating that student interpreters' FL anxiety had a lot to do with their fear of being less competent than their peers or their low self-confidence about their English ability. The rest of the items were items tapping situations similar to the three most anxiety-producing situations: aural English anxiety (rank 5), general English classroom anxiety (rank 7), and impromptu oral English anxiety (rank 9). These results were similar to the findings regarding the scope of FL anxiety analyzed by the individual FLCAS items.

\subsection{Severity of FL Anxiety in Student Interpreters by FLCAS Overall}

Table 2 displays the results regarding the severity of student interpreters' overall FL anxiety as compared with regular L 2 college students of various target languages in different cultures in previous studies that also used the FLCAS to examine students' FL anxiety.

TABLE 2

Severity of FL Anxiety in Student Interpreters vs Regular L2 College Students

\begin{tabular}{|llllll|}
\hline Study & Population & L 2 & N & Mean & SD \\
\hline Horwitz (1986) & USA & Spanish & 108 & 94.5 & 21.4 \\
Philips (1990) & USA & French & 44 & 99.3 & 24.6 \\
Aida (1994) & USA & Japanese & 96 & 96.7 & 22.1 \\
Palacios (1998) & USA & Spanish & 445 & 94.3 & 22.8 \\
Saito, Garza et al. (1999) & USA & French & 192 & 97.4 & 23.6 \\
Saito, Garza et al. (1999) & USA & Japanese & 114 & 93.5 & 18.9 \\
Tallon (2006) & USA & Spanish & 172 & 94.7 & 24.8 \\
Saito, Garza et al. (1999) & USA & Russian & 77 & 92.6 & 20.7 \\
Elkhafaifi (2005) & USA & Arabic & 233 & 90.0 & 23.8 \\
Zhang (2001) & China & English & 145 & 103.4 & 21.5 \\
Matsuta and Gobel (2004) & Japan & English & 252 & 100.7 & 11.4 \\
Cheng (1998) & Taiwan & English & 423 & 94.9 & 20.0 \\
\hline Present Study & Taiwan & English & $310^{*}$ & 92.9 & 17.8 \\
\hline
\end{tabular}

${ }^{\star} 17$ of the participants did not have complete data on the FLCAS, and hence were excluded from this analysis. 
As shown in Table 2, the level of FL anxiety experienced by Taiwanese interpretation students tended to be slightly lower than most university students of various nationalities learning different target languages. Compared with American students, the degree of Taiwanese interpretation students' FL anxiety was slightly lower than those reported in the literature, except the ones reported by Saito, Garza et al. (1999) and Elkhafaifi (2005): Horwitz (1986), Philips (1990), Aida (1994), Palacios (1998), Tallon (2006) and Elkhafaifi (2005) reported means of 94.5 for 108 students of Spanish, 99.3 for 44 students of French, 96.7 for 96 students of Japanese, 94.3 for 445 students of Spanish, 94.7 for 172 students of Spanish and 90.0 for 233 students of Arabic, respectively, while Saito, Garza et al. (1999) reported means of 97.4, 93.5, and 92.6 for American learners of French, Japanese, and Russian, respectively. That is, among American L2 learners, only American learners of Russian and Arabic had lower level of FL anxiety than Taiwanese student interpreters. Compared with Asian EFL students, the level of Taiwanese interpretation students' FL anxiety was less severe than those reported in previous empirical research: Zhang (2001) reported a mean of 103.4 for 145 Chinese EFL students, while Matsuda and Gobel (2004) reported a mean of 100.7 for 252 Japanese EFL learners. In a study examining Taiwanese English majors' anxiety, Cheng (1998) reported a mean of $94.9(\mathrm{n}=423)$, which was slightly higher than the mean of 92.9 found in the present study. It seemed that, except for American college students of Arabic and Russian, the severity of interpretation students' FL anxiety as a whole was slightly milder than most regular FL learners, though the difference was marginal.

\subsection{FL Anxiety in Student Interpreters vs Pooled FL Anxiety in Regular L2 Students}

In order to ascertain whether the level of FL anxiety in Taiwanese student interpreters was significantly different from the pooled anxiety level in regular L2 college students of different cultural groups with various target languages, a series of metaanalyses was performed to test the null hypothesis (effect size $=0$ ) that the finding of the present study did not differ from those reported in the literature on L2 college students. Specifically, before they were subjected to meta-analyses, the data in Table 2 were re-categorized into American and Asian Groups, with the former being further subdivided into two samples. Table 3 displays the re-categorization of the sample.

As shown in Table 3, the sample was divided into 4 groups. Group 1 consists of regular American L2 learners whose FL anxiety levels appear to be higher than that of student interpreters (92.9), while Group 2 is made up by American learners whose FL anxiety levels appear to be lower than that of student interpreters. Group 3 consists of regular Asian EFL learners from "Confucian Heritage Cultures" (Woodrow 2006: 308), including China, Japan, and Taiwan. Group 4 represents the student interpreters in the present study. The entire sample as well as its sub-sample was subject to meta-analyses in order to test the following four hypotheses: 
H1. The level of FL anxiety in Taiwanese student interpreters (Group 4) was the same as the pooled FL anxiety level in the entire sample of regular L2 college students (Groups $1+2+3)$.

$\mathrm{H} 2$. The level of FL anxiety in Taiwanese student interpreters (Group 4) was the same as the pooled FL anxiety level in regular American L2 college students of various target languages (Groups 1+2)

H3. The level of FL anxiety in Taiwanese student interpreters (Group 4) was the same as the pooled FL anxiety level in regular American L2 college students of Russian and Arabic combined (Group 2)

H4. The level of FL anxiety in Taiwanese student interpreters (Group 4) was the same as the pooled FL anxiety level in regular Asian L2 college students of English (Group 3).

TABLE 3

Severity of FL anxiety in Various Studies Divided by Cultural Groups

\begin{tabular}{|c|c|c|c|c|c|c|}
\hline Group & Study & Population & L2 & $\mathrm{N}$ & Mean & $\mathrm{SD}$ \\
\hline \multirow{7}{*}{1} & Horwitz (1986) & USA & Spanish & 108 & 94.5 & 21.4 \\
\hline & Philips (1990) & USA & French & 44 & 99.3 & 24.6 \\
\hline & Aida (1994) & USA & Japanese & 96 & 96.7 & 22.1 \\
\hline & Palacios (1998) & USA & Spanish & 445 & 94.3 & 22.8 \\
\hline & Saito, Garza, et al., (1999) & USA & French & 192 & 97.4 & 23.6 \\
\hline & Saito, Garza, et al., (1999) & USA & Japanese & 114 & 93.5 & 18.9 \\
\hline & Tallon (2006) & USA & Spanish & 172 & 94.7 & 24.8 \\
\hline \multirow[t]{2}{*}{2} & Saito, Garza, et al., (1999) & USA & Russian & 77 & 92.6 & 20.7 \\
\hline & Elkhafaifi (2005) & USA & Arabic & 233 & 90.0 & 23.8 \\
\hline \multirow[t]{3}{*}{3} & Zhang (2001) & China & English & 145 & 103.4 & 21.5 \\
\hline & Matsuta and Gobel (2004) & Japan & English & 252 & 100.7 & 11.4 \\
\hline & Cheng (1998) & Taiwan & English & 423 & 94.9 & 20.0 \\
\hline 4 & Present Study & Taiwan & English & 310 & 92.9 & 17.8 \\
\hline
\end{tabular}

The above hypotheses were tested using meta-analyses and the results were summarized in the table below.

TABLE 4

\section{Summary of Meta-analysis Results}

\begin{tabular}{|c|c|c|c|c|}
\hline Hypothesis tested & statistics & Chi-Square with df & P & critical value \\
\hline H1 & 32.8200 & 1 & 0.05 & 3.8415 \\
\hline H2 & 32.1415 & 1 & 0.05 & 3.8415 \\
\hline H3 & 1.9905 & 1 & 0.05 & 3.8415 \\
\hline H4 & 47.9400 & 1 & 0.05 & 3.8415 \\
\hline
\end{tabular}

As displayed in Table 4, Hypothesis 1 was rejected (statistics $=32.8200>$ critical value $=3.8415$ ), suggesting that the level of FL anxiety in Taiwanese student interpreters was significantly lower than the pooled FL anxiety level in the entire sample (Groups $1+2+3$ ) of regular L2 college students of various nationalities (USA, China, Japan, and Taiwan) with different target languages (Spanish, French, Japanese, Russian, Arabic). Hypothesis 2 was rejected as well (statistics $=32.1415>$ critical value $=3.8415$ ), suggesting that the level of FL anxiety in Taiwanese student inter- 
preters was significantly lower than the pooled FL anxiety level in the sub-sample (Groups 1+2) of regular American L2 college students with different target languages (Spanish, French, Japanese, Russian, Arabic). In contrast, the results of meta-analysis failed to reject Hypothesis 3 (statistics $=1.9905<$ critical value $=3.8415$ ), suggesting that the level of FL anxiety in Taiwanese student interpreters was no different from the pooled FL anxiety level in the sub-sample (Group 2) comprising only American learners of Russian and Arabic, though previous descriptive statistics seemed to suggest Taiwanese student interpreters had higher level of FL anxiety than American L2 learners of Russian and Arabic. Together, results concerning Hypotheses 2 and 3 indicate that the level of FL anxiety in Taiwanese student interpreters was significantly lower than the overall FL anxiety level of regular American L2 college students of different target languages, and the difference stems primarily from the relatively higher levels of FL anxiety in those learning Spanish, French, and Japanese, rather than those learning Russian and Arabic. Hypothesis 4 was rejected (statistics = $47.9400>$ critical value $=3.8415$ ), suggesting that the level of FL anxiety in Taiwanese student interpreters was significantly lower than the pooled FL anxiety level in regular Asian college students of English, including Chinese EFL learners, Japanese EFL learners, and Taiwanese EFL learners (Group 3).

\section{Discussion}

The present study provided the first empirical evidence regarding Taiwanese student interpreters' FL anxiety: Despite the language facility they were expected to possess as interpreters, Taiwanese student interpreters did experience FL anxiety, and both the magnitude and the scope of their FL anxiety were slightly less severe and less prevalent than those of most regular L2 learners. FL anxiety was found to prevail in over about 33\% of the students, a scope that was similar to that of American L2 learners, wider than the $20-25 \%$ found in European L2 learners, and lower than the $40-45 \%$ reported in Asian L2 learners. The fact that the scope of Taiwanese student interpreters' FL anxiety was smaller than Asian L2 learners perhaps indicated that on average, around $5-10 \%$ of the participants did have more confidence and/or a better language facility than regular Asian L2 learners, and were hence more immune to FL anxiety.

In the same vein, except for American learners of Arabic and Russian, Taiwanese student interpreters had a slightly lower FLCAS mean score (92.9) than most university L2 learners of various nationalities with various target languages, including American students of Spanish, French, and Japanese (Horwitz 1986; Philips 1990; Aida 1994; Palacios 1998; Saito, Garza et al. 1999; Tallon, 2006); Chinese EFL learners (Zhang 2001); Japanese EFL learners (Matsuda and Gobel 2004) and Taiwanese English majors (Cheng 1998). The results of meta-analyses further showed that Taiwanese student interpreters had significantly lower level of FL anxiety than the entire sample of regular L2 college students, the first group of American L2 learners, and Asian EFL learners from China, Japan, and Taiwan. Although descriptive statistics analyses seemed to indicate American college students of Russian and Arabic had lower anxiety levels than Taiwanese student interpreters, the difference turned out to be non-significant after being subject to meta-analysis. That Asian EFL learners had higher level of FL anxiety than Taiwanese student interpreters was no surprise at all as Asian L2 learners have been found be among the most anxious of all L2 learners 
in many studies, no matter whether the FLCAS was used as a measurement instrument (e.g., Horwitz 2001, 2008; Woodrow, 2006). What was surprising was the fact that Cheng's (1998) sample had a higher FLCAS mean than the sample in the present study. Whereas Cheng's sample was drawn from four Taiwanese universities with one usually considered middle-ranked, and the other three considered among the most prestigious, the sample in the present study was drawn from nine Taiwanese universities with three each usually ranked as follows: among the less prestigious, the middle-ranked, and the most prestigious. Given the makeup of Cheng's (1998) sample and that of the present study's, it should follow that Taiwanese student interpreters' FLCAS mean score be higher than the English majors' surveyed by Cheng (1998) if lower FL proficiency or achievement were indeed associated with higher FL anxiety as numerous studies have found (for a review, see Horwitz 2001).

However, the inclusion of students from less prestigious universities did not raise the mean of the sample in the present study, but instead resulted in its mean being lower than that of Cheng's (1998) sample. It was likely that high achieving L2 learners were afflicted with higher FL anxiety than their less able counterparts due to "keen competition, high self-expectations, unrealistic achievement goals, or rigid academic requirements" as Cheng (1998: 180) claimed, and thus the inclusion of lower achieving students in the present study's sample led to lower FLCAS means. On the other hand, it was also probable that no matter whether they were from the less prestigious or the more prestigious universities, many of the students who selfselected to take interpretation classes were less susceptible to FL anxiety in the first place, perhaps because they had either relatively higher proficiency or relatively more confidence in their listening and speaking abilities than students who opted not to take the course, and thus reduced the FLCAS mean of the present study's sample to a level lower than that of Cheng's (1998) participants.

A cross-study comparison of the FLCAS items in the present study with those in Cheng (1998) seems to support such an explanation. Table 5 presents the means of three self-confidence-related FLCAS items as rated by student interpreters in the present study and by English majors in Cheng (1998).

TABLE 5

Self-Confidence in English in Student Interpreters (SI) vs English Majors (EM)

\begin{tabular}{|c|l|c|c|c|c|}
\hline Item & \multicolumn{1}{|c|}{ Item Description } & \multicolumn{2}{c|}{ SI } & \multicolumn{2}{c|}{ EM } \\
\cline { 3 - 5 } & & Mean & $\%^{6}$ & Mean & $\%$ \\
\hline 1 & $\begin{array}{l}\text { I always feel that the other students speak English } \\
\text { better than I do. }\end{array}$ & 3.17 & 39 & 3.22 & 45 \\
\hline 2 & $\begin{array}{l}\text { I keep thinking that the other students are better at } \\
\text { English than I am. }\end{array}$ & 3.13 & 37 & 3.35 & 50 \\
\hline 3 & $\begin{array}{l}\text { I (do not) feel confident when I speak English in } \\
\text { English class. }\end{array}$ & 3.08 & 29 & 3.25 & 39 \\
\hline
\end{tabular}

As shown in Table 5, around 6\% to $13 \%$ of student interpreters seemed to have more self-confidence or less fear of unfavorable social comparisons than English majors, and hence their FL anxiety as a whole was rated as being less severe. It should be emphasized that although a higher percentage of student interpreters might have 
more self-confidence in English than English majors, around 29\% to 39\% of them were unsure about communicating in English as a result of lack of self-efficacy or fear of being less competent than their fellow students. Chiang's (2006) analysis of the underlying structure of student interpreters' FL anxiety lent further support to such an explanation: Taiwanese student interpreters' FL anxiety was found to share with regular L2 learners' anxiety in language classroom performance anxiety, particularly in the dimension of communication and negative evaluation anxiety with low selfconfidence as its latent factor. That is, while low self-confidence in English may not be an issue for some student interpreters, it was a problem to overcome for others.

\section{Conclusion}

This study investigated the scope and severity of FL anxiety in Taiwanese student interpreters. Results showed that about one-third of Taiwanese student interpreters had FL anxiety, a scope smaller than Asian L2 learners', similar to American L2 learners', and wider than European L2 learners', and the level of Taiwanese student interpreters' FL anxiety was slightly lower than most university learners of various nationalities with various target languages, including American students of Spanish, French, and Japanese (Horwitz, Horwitz et al. 1986; Philips 1990; Aida 1994; Palacios 1998; Saito, Garza et al. (1999); Tallon 2006); Chinese EFL learners (Zhang 2001); Japanese EFL learners (Matsuda and Gobbel 2004) and Taiwanese English majors (Cheng 1998), except for American college students of Arabic and Russian (Elkhafaifi 2005; Saito, Garza et al. 1999). Such differences in the scope and severity of Taiwanese student interpreters' FL anxiety might be attributed to the fact that around one out of ten Taiwanese student interpreters seemed to have more self-efficacy in English than regular Asian L2 learners, though low self-confidence remained an issue to overcome for around one-third of student interpreters.

The findings of the present study have important implications for pedagogy and future research. In terms of pedagogy, interpretation instructors first should recognize that about one-third of student interpreters might suffer from FL anxiety, though their FL anxiety is slightly less prevalent and less severe than regular Asian L2 learners'. Despite the English language facility expected of them, student interpreters were anxious about both English listening and speaking - the two essential skills on which interpretation competence is built - with their FL listening anxiety stemming primarily from comprehending what the teacher said in English, and their FL speaking anxiety deriving mainly from impromptu English communication and question-andanswer sessions. In addition, the individual FLCAS item analyses also found that low self-confidence or fear of being less competent than their peers was a problem for student interpreters to overcome. To alleviate student interpreters' FL anxiety, instructors can provide their students with "comprehensible" English "input" (Krashen 1981: 16) when students are learning to interpret from English to Chinese or give them ample time for preparation and practice when students are learning to interpret from Chinese into English. Regardless of whether interpreting into or from English, it is important for instructors to lower students' "affective filters" (Krashen 1981: 16) by building their students' self-confidence in the interpretation classroom. To achieve this, instructors can modify Krashen's (1981) i + 1 language-teaching principle into an i or i - 1 interpretation-teaching principle if they know their students' 
English is at the level of i. (According to Krashen's Comprehensible Input Hypothesis, L2 learners improve their linguistic competence when they receive "comprehensible" L2 "input" that is one level beyond their current L2 level. For instance, if learners are at a level ' $i$,' then their L2 acquisition occurs when they receive 'Comprehensible Input' that belongs to level ' $i+1$ '). By doing so, instructors can create ample opportunities for their students to experience successes and help them build their selfconfidence in English, and hopefully their anxiety about English speaking and listening will be reduced, if not removed, and their anxiety about interpretation will be alleviated as well in the long run. However, as student-teacher interaction in each interpretation classroom is likely to vary greatly from one to another, instructors are strongly encouraged to use validated FL anxiety measures, such as the FLCAS (Horwitz, Horwitz et al. 1986) to diagnose the sources, scope and severity of FL anxiety in their own students, so that they can effectively intervene in their students' learning with appropriate instructional methods.

While shedding some light on the scope and severity of FL anxiety in student interpreters, the present study only bridges a small gap between FL anxiety research and interpretation anxiety research. More interdisciplinary studies between these two fields are needed to build a more comprehensive understanding of the role and influence of FL anxiety in student interpreters' learning in general and in their anxiety about interpretation in particular. Because the findings of this study were generated from English-Chinese interpretation students in Taiwan, these results cannot be generalized to other populations with different language combinations from other educational settings. Future research can investigate the scope and severity of FL anxiety in postgraduate students who are learning to interpret between Chinese and other foreign languages, such as Japanese, French, Spanish, or German, or in interpretation students from other cultural backgrounds with a different language combination, such as Korean-English, or French-Italian. In addition, because the present study only examined the scope and severity of FL anxiety in interpretation students without investigating the influence of FL anxiety on their learning, future studies can investigate whether FL anxiety is linked to students' learning outcomes in interpretation courses.

\section{ACKNOWLEDGEMENTS}

This paper is based in part upon the author's doctoral dissertation under the guidance of Dr. Elaine Horwitz and Dr. Diane Schallert, to whom the author is greatly indebted. Special thanks also go to Dr. Elaine Horwitz, Dr. Yuh-show Cheng, Dr. Lisa Palacios (now Dr. McClear), Dr. Elaine Philips, and Dr. Michael Tallon for giving me permission to use their data in this paper, to Dr. Chia-hao Chang for helping me with the meta-analyses, and to Pr. Sylvie Vandaele for her meticulous editorial efforts.

\section{NOTES}

1. Second language (L2) acquisition is used here as a cover term for both second and foreign language learning situations. L2 learning takes place in situations where the language plays an institutional and social role in the community. For instance, examples of learning English as an L2 are English learned by non-native English speakers in the US or in the UK. In contrast, FL learning takes place in settings where the language does not play a major role in the community and is primarily learned in the classroom. Examples of learning English as a FL are English learned in the Taiwan or Japan. (For further information, see Platt, Richard et al. (1992) Longman Dictionary of Language Teaching and Applied Linguistics. $2^{\text {nd }}$ ed. London: Longman, 142-143). 
2. As will be pointed out later, interpretation stress and interpretation anxiety are often used interchangeably in interpretation literature; from here on, unless a distinction is intended, "interpretation anxiety" is used to reduce the clumsiness of writing and to further highlight the connection to $\mathrm{L} 2$ anxiety research.

3. Since anxiety can be measured by various means, only studies that employed or included psychological measurement instruments are reviewed here.

4. In most of these classes, the focus was on consecutive interpretation. However, simultaneous interpretation was also taught in some of these classes in the second semester.

5. As noted earlier, the FLCAS items were scored in such a way that higher means reflect higher anxiety.

6. The percentage refers to those who agreed and strongly agreed combined.

\section{REFERENCES}

AIDA, Yukie (1994): Examination of Horwitz, Horwitz, and Copes' construct of foreign language anxiety - the case of students of Japanese. Modern Language Journal. 78(2):155-168.

AIIC (2002): The Workload Study. Visited on January $18^{\text {th }}, 2005,<$ http://www.aiic.net/ViewPage. cfm/article659>.

Alexieva, Bistra (1997): A typology of interpreter-mediated events. The Translator. 3(2):153174.

Brisau, Andre, Godijns, Rita. and Meuleman, Chris (1994): Toward a psycholinguistic profile of the interpreter. Meta. 39(1):87-94.

Campbell, Christine M. and Ortiz, Jose (1991): Helping students overcome foreign language anxiety: A foreign language anxiety workshop. In: Elaine K. Horwitz and Dolly J. Young, eds. Language anxiety: From theory and research to classroom implications. Englewood Cliffs, NJ: Prentice Hall, 153-168.

Cheng, Yuh-show (1998): Examination of two anxiety constructs: Second language class anxiety and second language writing anxiety. Unpublished doctoral dissertation, University of Texas, Austin.

Chiang, Yung-nan (2006): Connecting two anxiety constructs: An interdisciplinary study of foreign language anxiety and interpretation anxiety. Unpublished doctoral dissertation, University of Texas, Austin.

Cooper, Cary L., Davis, Rachel, and Tung, Rosalie L. (1982): Interpreting stress: sources of job stress among conference interpreters. Multilingual. 1(2):97-107.

Coughlin, Josette M. (1988): Inside or between languages, oral communication equals interpretation. In: Deanna L. Hammond, ed. Language at Crossroads. Proceedings of the $29^{\text {th }}$ Annual Conference of the American Translators Association. Medford, NJ: Learned information, 105-113.

DJigunovic, Jelena Mihaljevic (2006): Language anxiety and language processing. EUROSLA Yearbook. 6:191-212.

Elkhafaifi, Hussein (2005): Listening comprehension and anxiety in the Arabic language classroom. The Modern Language Journal. 89(2):206-220.

GaibA, Francesca (1998): The Origin of Simultaneous Interpretation: The Nuremberg Trial. Ottawa: Ottawa University Press.

Gerver, David (1974): The effects of noise on the performance of simultaneous interpreters. ACTA Psychologica. 38(3):159-167.

Gile, Daniel (1995): Basic Concepts and Models for Interpreter and Translator Training. Amsterdam: John Benjamins.

Herbert, Jean (1952): The Interpreter's Handbook: How to Become a Conference Interpreter. Geneva: Librairie de l'Université.

Horwitz, Elaine K., Horwitz, Michael B. and Cope, Joanne (1986): Foreign language classroom anxiety. In: Elaine K. Horwitz and Dolly J. Young, eds. Language anxiety: From theory and research to classroom implications. Englewood Cliffs, NJ: Prentice Hall, 27-36. 
Horwitz, Elaine K. (1986): Preliminary evidence for the reliability and validity of a foreign language anxiety scale. In: Elaine K. Horwitz and Dolly J. Young, eds. Language anxiety: From theory and research to classroom implications. Englewood Cliffs, NJ: Prentice Hall, 37-40.

Horwitz, Elaine K., and Young, Dolly J., ed. (1991): Language anxiety: From theory and research to classroom implications. Englewood Cliffs, NJ: Prentice Hall.

Horwitz, Elaine K. (2001): Language anxiety and achievement. Annual Review of Applied Linguistics. 21:112-126.

Horwitz, Elaine K. (2005): On learners, teachers, and pink dresses. Paper presented at the Foreign Language Education Forum, Austin, Texas.

Horwitz, Elaine K. (2008): Becoming a Language Teacher: A Practical Guide to Second Language Learning and Teaching. Boston: Allyn \& Bacon.

Jiménez, Ivars and Pinazo, Daniel (2001): "I failed because I got very nervous." Anxiety and performance in interpreting trainees: An empirical study. The Interpreters' Newsletter. 9:21-39.

KeISER, Walter (1997): Selection and training of conference interpreters. In: David GeRVER and Wallace H. Sinaiko, eds. Language, Interpretation and Communication. New York: Plenum Press, 11-24.

KLonowicz, Tatiana (1991): The effort of simultaneous interpretation: It's been a hard day.... FIT Newsletter, 10(4):446-457.

Klonowicz, Tatiana (1994): Putting one's heart into simultaneous interpretation. In: Sylvie Lambert and Barbara Moser-Mercer, eds. Bridging the gap: Empirical research in simultaneous interpretation. Amsterdam: John Benjamins, 213-224.

KuRz, Ingrid (1997): Interpreters: stress and situation-dependent control of anxiety. In: Kinga KLAudy and János KoHN, eds. Transferre Necesse Est. Proceedings of the $2^{\text {nd }}$ International Conference on Current Trends in the Studies of Translation and Interpreting. Budapest: Scholastica, 201-206.

Krashen, Stephen D. (1981): Principles and Practice in Second Language Acquisition. London: Prentice-Hall International.

Macintyre, Peter. D. and Gardner, Robert C. (1991): Language anxiety: its relationship to other anxieties and to processing in native and second languages. Language Learning. 41(4):513-534.

Macintyre, Peter. D. and Gardner, Robert C. (1994): The subtle effects of language anxiety on cognitive processing in the second languages. Language Learning. 44(2):283-305.

Matsuta, Sae and Gobel, Peter (2004): Anxiety and predictors of performance in the foreign language classroom. System. 32(1):21-36.

Moser-Mercer, Barbara, Kunzli, Alexander and Korac, Marina (1998): Prolonged turns in interpreting: Effects on quality, physiological and psychological stress (pilot study). Interpreting: International Journal of Research and Practice in Interpreting. 3(1):47-64.

Moser-Mercer, Barbara (2003): Remote interpreting: Assessment of human factors and performance parameters. Visited on May $26^{\text {th }}, 2005$, $<$ http://www.aiic.net/ViewPage.cfm?page_id=1125>.

Palacios, Lisa M. (1998): Foreign language anxiety and classroom environment: A study of Spanish university students. Unpublished doctoral dissertation, University of Texas, Austin.

PHILlips, Elaine M. (1990): The effects of anxiety on performance and achievement in an oral test of French. Unpublished doctoral dissertation, University of Texas, Austin.

Riccardi, Alessandra, Marinuzzi, Guido and Zecchin, Stefano (1998): Interpretation and stress. The Interpreters' Newsletter. 18:93-106.

Richard, Jack C., Platt, John and Platt, Heidi (1992): Longman Dictionary of Language Teaching and Applied Linguistics. London: Longman.

RolAnd, Ruth A. (1982): Translating world affairs. London: McFarland.

Saito, Yoshiko, Garza, Thomas J. and Horwitz, Elaine (1999): Foreign language reading anxiety, Modern Language Journal. 83(2):202-218. 
Seleskovitch, Danica (1978): Interpreting for International Conferences. Washington, DC: Pen and Booth.

Spielberger, Charles D. and Gorsuch, Richard L. (1983): Manual for State-Trait Anxiety Inventory (Form Y). Palo Alto, CA: Consulting Psychologists Press.

TALlON, Michael (2006): Foreign language anxiety in heritage students of Spanish: To be (anxious) or not to be (anxious)? that is the question. Unpublished doctoral dissertation, University of Texas, Austin.

Woodrow, Lily (2006): Anxiety and speaking English as a second language. RELC Journal. 37(3):308-328.

ZHANG, Lawrence Jun (2001): Exploring variability in language anxiety: two groups of PRC students learning ESL in Singapore. RELC Journal. 32(1):73-91. 